\title{
Floral Biology, Psychophily, Anemochory and Zoochory in Chromolaena odorata (L.) King and H.E. Robins (Asteraceae)
}

\author{
Pakkurti Vara Lakshmi, Aluri Jacob Solomon Raju*, Dandangi Jeevan Ram \\ and Kunuku Venkata Ramana \\ Department of Environmental Sciences, Andhra University, Visakhapatnam 530 003, India
}

(received August 25, 2010; revised January 6, 2011; accepted January 18, 2011)

\begin{abstract}
The study investigates the pollination biology of Chromolaena odorata an exotic species of India, and also its importance as forage source for insects especially butterflies. The plant possesses floral characteristics typifying psychophily. It is an important nectar source for insects and attracts butterflies, hawk moths, bees, wasps, flies and other insects, which act as facultative pollinators while collecting the forage. Among the butterflies, Nymphalids play a prime role in the pollination. Seed set rate is very high in each head inflorescence in open pollination. Seed dispersal is by both anemochorous and zoochorous modes but former is the principal one.
\end{abstract}

Keywords: Chromolaena odorata, nectar, psychophily, insects, anemochory, zoochory, pollination, butterflies

\section{Introduction}

Plant-insect interactions are important to understand the invasiveness of certain exotic weeds around the world. Invasive species threaten the native biological diversity of any ecosystem (Dupont et al., 2002) by interacting with native species in several ways. Many introduced plant species compete with natives for resources (Daehler, 2003) or benefit from mutualistic interactions with native resident species, often to the detriment of native mutualism (Traveset and Richardson, 2006; Richardson et al., 2000). Several studies have described the disruption of plant-animal interactions caused by competition for pollinators between invasive exotics and native plants (Moragues and Traveset, 2005). On the contrary, Larson (2008) reported that invasive plants often occur in monotypic stands and provide a dense source of sustenance for insects that rely on floral resources. A dense stand of flowering invasive plant may attract more pollinators to the area, and in the process enhances pollination of neighbouring natives also. It is in this context, the study has been contemplated to understand how Chromolaena odorata, an exotic species in India, is able to thrive well and attract a guild of insect species during its flowering season in order to achieve great success in sexual reproduction and in seed dispersal to expand its distribution range in the world. This paper describes the pollination biology of $C$. odorata and

*Author for correspondence; E-mail: solomonraju@gmail.com the importance of this plant as forage source for insects, especially butterflies. The notable finding in this work is that $C$. odorata is an important nectar host plant for local butterflies and at the same time butterflies are contributing to the expansion of the distribution range through fertilization of flowers and subsequent seed set.

\section{Materials and Methods}

Chromolaena odorata is a noxious perennial weed. It is a free standing shrub and grows up to $1 \mathrm{~m}$. It is maintained by a system of abundant, yellowish, fine lateral roots. The opposite, three-nerved leaves are ovate-lanceolate, usually with a dentate margin and a long pointed tip. Seed germination starts in May-June and active growth occurs during JuneOctober. Their shoots root when touching the ground. The plant possesses underground organs which ensure the plant survival during drought or mechanical damage or in case of fire. Flowering occurs once in a year. Flowers are very small, white to light purple, bisexual and zygomorphic. Calyx is reduced to pappus and represented by hairs. Corolla is tubular with five teeth at the tip. Stamens are 5, epipetalous, arise from the base of the corolla, with filaments free but anthers united, representing syngenesious condition. The anthers are dithecous, have their connective prolonged into hood and their bases produce hairy outgrowths, which in turn form a protective envelope for the nectary. The ovary is 
bicarpellary and syncarpous, unilocular with a single basal ovule (Fig. 1i,j). The style is surrounded by the nectary at the base and it is forked into two parts.

The the present study, C. odorata was found at an elevation of over $700 \mathrm{~m}$ in the Seshachalam Hills of southern eastern ghats (lat. $17^{\circ} 43^{\prime} \mathrm{N}$; long. $83^{\circ}$ $90^{\prime} \mathrm{E}$ ) of Andhra Pradesh, India in open, sunny areas of forest margins and open gaps in the forest and was used for the study during the summer season of 2009. $C$. odorata grows profusely during the active growth period and suppresses the growth of native low ground herbaceous flora. Twenty five tagged mature buds, five each from five individuals were followed for recording the time of anthesis and anther dehiscence; the mode of anther dehiscence was also noted by using a $10 \times$ hand lens. Pollen was collected from ten mature but undehisced anthers of staminate flowers of five different plants. Each anther was dabbed with a needle in a drop of lactophenolaniline-blue. The anther tissue was then observed under compound microscope and the total number of pollen grains was counted. The mean pollen output per anther was multiplied by the number of anthers of a flower for obtaining the mean number of pollen grains per flower. The pollen-ovule ratio was determined as per Dafni et al. (2005). Twenty five flowers, five each from five individuals were used to test stigma receptivity with hydrogen peroxide from mature bud stage to flower drop (Dafni et al., 2005). Regular observations were made on the insect species visiting the flowers for forage. The insects were observed for their foraging behaviour such as mode of approach, landing, probing behaviour, the type of forage they collect, contact with essential organs to result in pollination and inter-plant foraging activity in terms of cross-pollination. The observation days for these aspects were thirty and the time spent each day was five to eight hours. Twenty flowers each from fifty plants were selected for collecting information on insect activity. Three to five specimens of each butterfly species collected at different times of the day were brought to laboratory for examining their proboscis under microscope for the presence of pollen grains in order to assess their role in pollen transfer and pollination. Fruit and seed aspects were recorded based on fifty sample heads collected from ten plants. A sample of ten tagged cylindrical heads consisting of 489 flowers was followed for fruit set rate in open-pollination. Field studies were carried out also for seedling aspects.

\section{Results and Discussion}

Floral biology. Flowering occured during OctoberDecember. The inflorescences consisted of corymbs of cylindrical heads, emerging at the terminal part of the branches (Fig. 1a). A head consisted of 21 to 28 tubular florets (Fig. 1b,c). The florets opened during 0600$0800 \mathrm{~h}$ (Fig. 1d-g). The anthers dehisced by longitudinal slits prior to anthesis. The pollen grains were $196 \pm 14.6$ per anther and the total pollen output per floret was $980 \pm 11.8$ (Fig. 1h). The pollen-ovule ratio was 980:1. The narrow anthers form a hollow space and pollen is liberated into this space. The receptive surfaces of the stylar branches stayed in closed state and as they grew through the hollow space, brushed out the pollen liberated in the hollow space. Further, the style stretched out beyond the anthers, and spread out its branches which then became receptive and ready to receive pollen from the foragers. The receptivity remained so until the noon of the $2^{\text {nd }}$ day and the stylar branches withered away gradually. The nectar was secreted in traces only. The florets remained in place for about 3-4 days and later fell off if not pollinated.

Flower visitors and pollination. The florets were visited during day time by butterflies for nectar collection and by other insects for pollen and/or nectar collection; and by diurnal hawk moths, during dawn and dusk hours for nectar collection. The butterflies included 23 species representing Papilionidae, Pieridae, Nymphalidae, Lycaenidae and Hesperiidae (Table 1; Fig. 1l-p; Fig. 2a-i). Foraging activity of nymphalid butterflies showed a general trend characterized by gradual increase from morning to noon and gradual decrease towards the evening (Fig. 4). This foraging trend was observed almost throughout the flowering season for butterflies of all families during this study. The data collected on the foraging visits of butterflies of each family showed that Nymphalids made $61 \%$, Papilionids $17 \%$, Pierids $11 \%$, Lycaenids $8 \%$ and Hesperiids $3 \%$ of the total visits. The cylindrical heads equipped with a cluster of florets provided convenient landing place for butterflies and this arrangement also enabled them to probe several flowers during each visit in succession for nectar before their departure. The flowering heads borne terminally stood out prominently and the butterflies were found to be attracted to them even from a long distance. The butterfly proboscides 


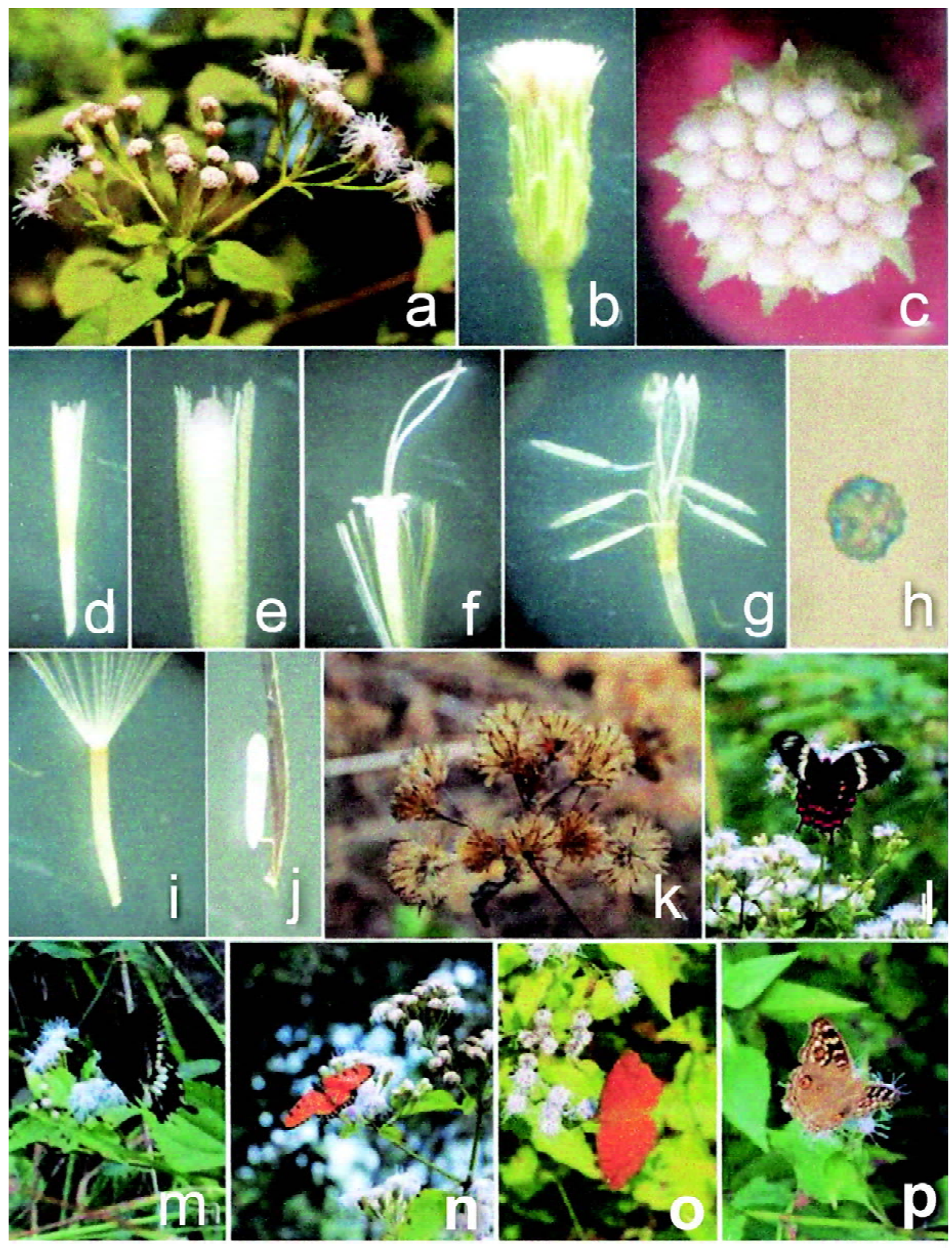

Fig. 1. Chromolaena odorata: a. Flowering inflorescences; b. Individual cylindrical head; c. Mature head; d. \& e. Mature florets; f. Open floret; g. L. S. floret; h. Pollen grain; i. Ovary; j. Ovule; k. Mature seeds ready for dispersal; l. Pachliopta hector; m. Papilio polytes; n. Acraea violea; o. Ariadne ariadne; p. Junonia lemonia. 


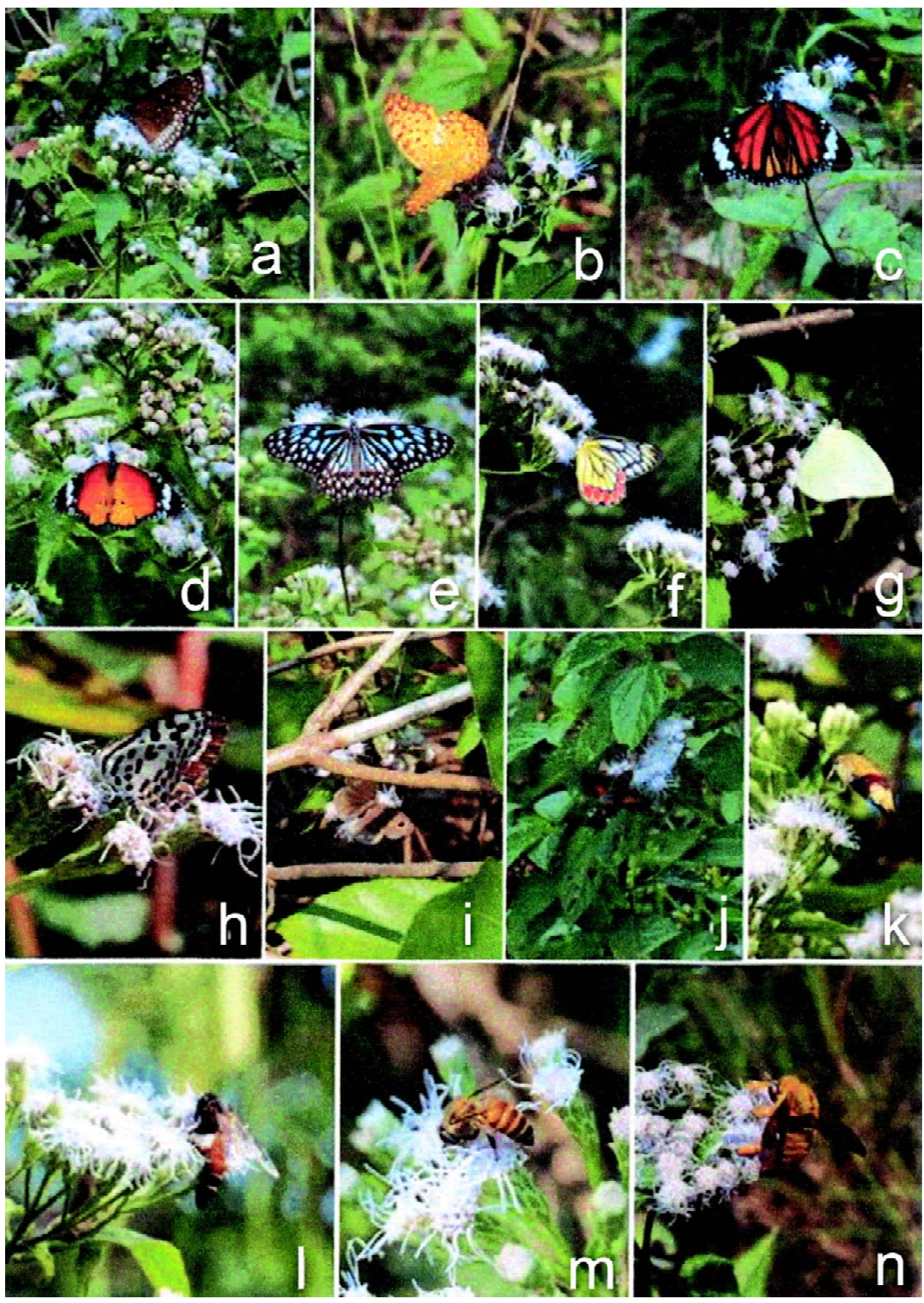

Fig. 2. Chromolaena odorata: a. Euploea core; b. Phalanta phalantha; c. Danaus genutia; d. Danaus chrysippus; e. Tirumala limniace; f. Delias eucharis; g. Catopsilia pyranthe; h. Tarucus nara; i. Ypthima asterope; j. Macroglossum gyrans; k. Cephonodes hylas; l. Apis dorsata; m. Apis cerana; n. Xylocopa sp. 
Table 1. List of insect foragers on Chromolaena odorata

\begin{tabular}{|c|c|c|}
\hline Family & Scientific name & Common name \\
\hline \multicolumn{3}{|l|}{ Lepidoptera } \\
\hline \multirow[t]{3}{*}{ Papilionidae } & Pachliopta hector & Crimson Rose \\
\hline & Papilio polytes & Common Mormon \\
\hline & Papilio demoleus & Lime Butterfly \\
\hline \multirow[t]{3}{*}{ Pieridae } & Catopsilia pyranthe & Mottled Emigrant \\
\hline & Anaphaeis aurota & Pioneer \\
\hline & Delias eucharis & Common Jezebel \\
\hline \multirow[t]{14}{*}{ Nymphalidae } & Ariadne ariadne & Angled Castor \\
\hline & Junonia lemonias & Lemon Pansy \\
\hline & Junonia hierta & Yellow Pansy \\
\hline & Precis iphita & Chocolate Pansy \\
\hline & Acraea violae & Tawny Coster \\
\hline & Euploea core & Common Indian Crow \\
\hline & Phalanta phalantha & Common Leopard \\
\hline & Danaus genutia & Striped Tiger \\
\hline & Danaus chrysippus & Plain Tiger \\
\hline & Ypthima asterope & Common Three- Ring \\
\hline & Melanitis leda & Common Evening Brown \\
\hline & Tirumala limniace & Blue Tiger \\
\hline & Parantica aglea & Glassy Tiger \\
\hline & Neptis hylas & Common Sailer \\
\hline \multirow[t]{2}{*}{ Lycaenidae } & Everes lacturnus & Indian Cupid \\
\hline & Tarucus nara & Rounded Pierrot \\
\hline Hesperiidae & Borbo cinnara & Rice Swift \\
\hline \multirow[t]{2}{*}{ Sphingidae } & Cephonodes hylas & Coffee Hawk moth \\
\hline & Macroglossum gyrans & Diurnal Hawk moth \\
\hline \multicolumn{3}{|l|}{ Hymenoptera } \\
\hline \multirow[t]{4}{*}{ Apidae } & Apis dorsata & Rock Honey Bee \\
\hline & Apis cerana & Indian Honey Bee \\
\hline & A. florea & Dwarf Honey Bee \\
\hline & Xylocopa sp. & Large Carpenter Bee \\
\hline Crabronidae & Stizus sp. & Digger Wasp \\
\hline \multirow[t]{2}{*}{ Scoliidae } & Scolia quadripustulata & Blue-winged Wasp \\
\hline & Scolia sp. & Blue-winged Wasp \\
\hline \multicolumn{3}{|l|}{ Diptera } \\
\hline Syrphidae & Helophilus sp. & Hover Fly \\
\hline
\end{tabular}

invariably contained pollen grains ranging from 15-35 in Papilionids, 14-23 in Pierids, 29-189 in Nymphalids, 8-17 in Lycaenids and 9-21 in Hesperiids. All these butterflies stretched out their proboscis to reach the floret base for accessing nectar; while doing so the proboscis invariably contacted the stylar surfaces and hence affected pollination. They frequently moved between individual plants of $C$. odorata which had patchy distribution along the forest margins and in the open gaps of the forest interior.

Hawk moths (Fig. 2j,k) showed intense foraging activity during dawn hours, when the florets offered fresh nectar, while reduced activity during dusk hours when the florets offered only the left-over nectar which was not fresh; they rarely foraged during daytime. They hovered over the floret heads, inserted the proboscis, and collected nectar quickly from as many florets as possible from several flowering heads in quick succession. Their proboscis gained contact with the stylar surfaces of each floret they visited and this contact was considered to be resulting in pollination. They collected nectar from a number of plants within a patch and in different patches contributing to cross-pollination.

Other insect foragers included Hymenoptera and Diptera (Table 1; Fig. 2 l-n, Fig. 3 a-d). Of these, bees and wasps were frequent foragers during flowering peak season in November; other foragers visited the florets/heads occasionally. They approached the flowering plants in upright position and landed on the head inflorescences prior to probing the florets. Bees were found to probe the florets for nectar as well as pollen; it was not clear whether they were successful in getting the nectar with their short proboscides but they voraciously collected pollen. The wasps and other insects probed the flowers to collect nectar only; their success depended on the force with which they stretched out their tongue into the tubular corolla for nectar collection.

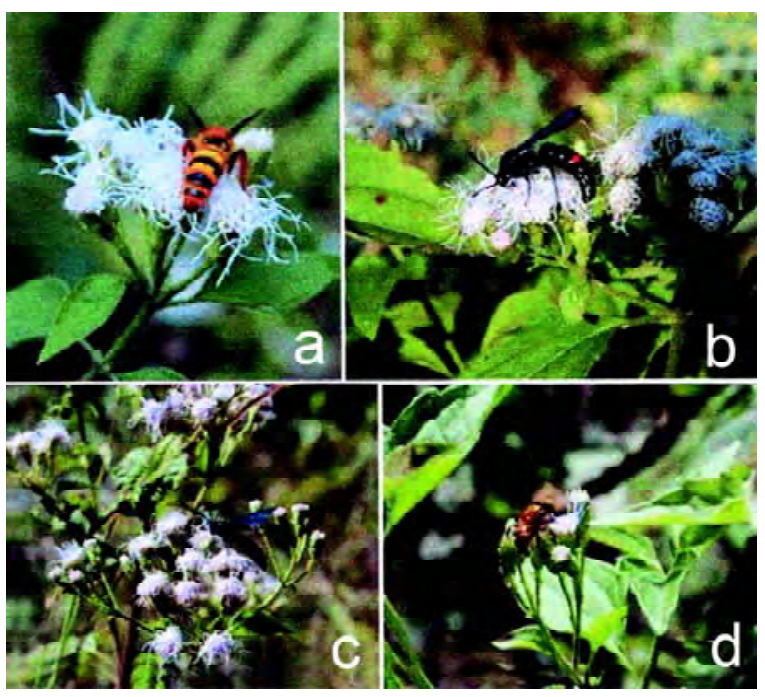

Fig. 3. Chromolaea odorata: a. Stizus sp.; b. Scolia guadripustulata; c. Scolia sp.; d. Helophilus sp.

Fruiting ecology. Natural fruit set was $89 \%$. The fruits were small and one-seeded. The seeds were dry, light and $4 \mathrm{~mm}$ long, brownish grey to black achene with a small hook and tipped with pale brown 5-6 mm long 
pappus (Fig. 1k). The pappus acted as float and helped in seed dispersal. The plants achieved maximum fruiting in January and the seeds matured by March. The seeds were effectively dispersed by wind and also by goats, buffaloes and cows during April-May; the small hooks on the seed facilitated dispersal by animals and man. Seed germination started in the late May-June following the first showers and subsequent monsoonal rainfall. They quickly germinated and produced new plants in open areas; the success of this plant as a weed was found to be related to its early seed germination and formation of new plants before the growth of the herbaceous flora during rainy season.

C. odorata florets in cylindrical heads conformed to psychophily. The floral characteristics that typified psychophily included white to purple colour of florets and short tubed corolla with nectar located at the base (Faegri and van der Pijl, 1979). The morning anthesis, protandry and stigma receptivity soon after anthesis were additional traits that facilitated pollination by butterflies and other insects. The flat-topped head inflorescences provided a standing platform and opportunities for walking by foragers between inflorescences. Baker and Baker (1983) mentioned that the short-tubed flowers constituted "bee and butterflyflowers" since the short-tubed florets facilitated foraging by short-tongued bees and butterflies having short to long proboscis. The retention of florets beyond the duration of stigma receptivity may have enhanced the attractiveness of flowering heads to visiting butterflies and other insects (van Doorn, 2002). C. odorata with these floral structural and functional characteristics attracted butterflies, hawk moths, bees and other insects. The butterflies of all families of Lepidoptera collected nectar from the flowering heads as soon as the florets were open and in so doing very likely affected both self- and cross-pollination. Since the florets secreted traces of nectar, the butterflies in quest of nectar visited as many florets and flowering heads as possible in a single foraging visit, the foraging behaviour of which promoted cross-pollination. The patchy distribution of the plant with numerous flowering heads facilitated frequent movement of butterflies between different individuals and such a movement promoted cross-pollination definitely. Since the florets are short-tubed, the butterflies with any length of proboscis collected nectar without any difficulty. The florets borne on cylindrical heads collectively offer considerable quantity of nectar and are energetically profitable for butterflies since such an arrangement reduces search time and flight time. The proboscides of butterflies carried and transferred pollen to different plants. Among the butterflies, Nymphalids frequented the flowers consistently throughout the season by individual numbers and species, and hence played prime role in the pollination than other butterflies. In another exotic family

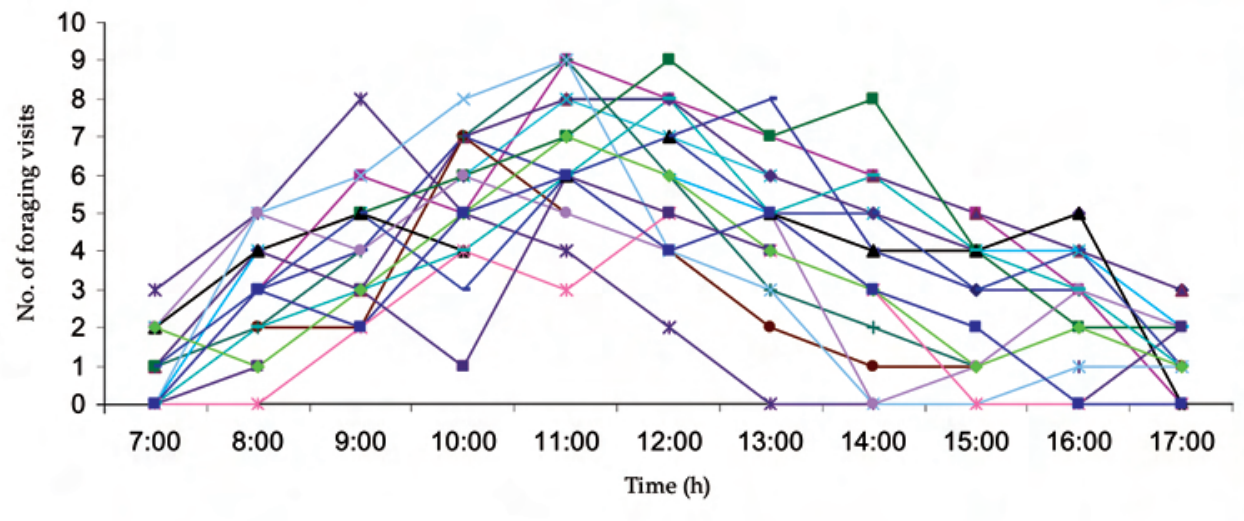

Fig. 4. Hourly nectar foraging activity of butterflies on Chromolaena odorata.

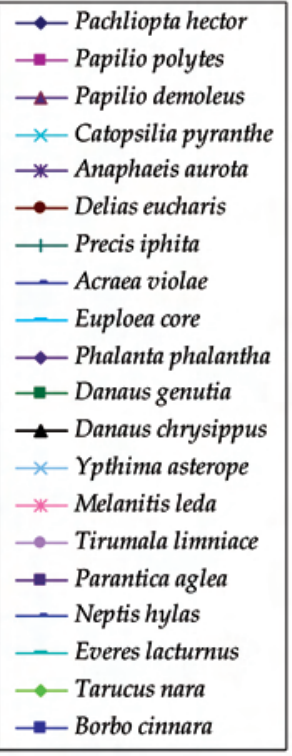


Asteraceae, Tridax procumbens Danaid and Pierid butterflies have been shown to be the main pollinators (Balasubramaniam, 1989). Therefore, psychophily is adaptive and advantageous for the plant to maximize pollination with specialized florets and nectarivore of butterflies.

The diurnal hawk moths, Macroglossum gyrans and Cephonodes hylas, also visited $C$. odorata flowering heads during dawn and dusk hours. The dawn foraging activity is energetically profitable for them while the foraging at dusk period may not be profitable as the florets by that time are most likely to be devoid of nectar due to butterflies and other insects during day time. They collected nectar on clear sunny and rainy days and utilized this floral source until exhausted. Balasubramaniam (1989) reported that hawk moths visited the florets of Tridax procumbens during rainy weather when most butterflies took shelter among foliage in nearby bushes.

Balasubramaniam (1989) reported that honey bees, flies, ants and thrips acted as facultative pollinators of Tridax procumbens. In the present study, bees visited the flowering heads to probe both nectar and pollen but it was not clear whether they accessed the nectar; however, they collected pollen voraciously and easily. The wasps and flies also visited the flowering heads; the former collected nectar easily with their tongue lengths exceeding the corolla tube while the latter attempted to collect nectar but it was not clear whether they were successful in nectar collection. Nevertheless, bees, wasps and flies affected pollination while collecting the forage; they may be designated as facultative pollinators since they visited the florets/heads during peak flowering season or occasionally. Further, the pollen collecting activity of bees can contribute to the unavailability of pollen for pollination purpose and hence they acted primarily as pollen thieves. The study shows that $C$. odorata being an exotic plant is psychophilous and its prevalence in the forest areas is a potential source of nectar for butterflies for a period of three months. Although it is a menace due to its prevalence and suppressive activity on the growth of certain native low ground herbs, its flowers are most attractive to butterflies throughout its distribution range and act as a provisioning post for the butterflies.
In C. odorata, seed production is prolific in each head inflorescence in open pollination. The fruit produces a single seed due to the presence of a single ovule in each floret (Fig $1 \mathrm{i}, \mathrm{j}$ ). Anemochory is the principal mode for seed dispersal; it is highly effective due to seed dispersal during summer season when ambient temperature is high and relative humidity is very low. Further, zoochory is also functional due to the presence of small hooks on the seeds; animals especially domestic animals as well as humans disperse seeds. Therefore, the dual modes of seed dispersal are instrumental in spreading the plant in the tropical latitudes rapidly (Kushwaha et al., 1981).

\section{References}

Baker, H.G., Baker, I. 1983. Floral nectar sugar constituents in relation to pollinator type. In: Handbook of Experimental Pollination Biology, C.E. Jones and R.J. Little (eds.), pp. 117-141, Van Nostrand Rheinhold, New York, USA.

Balasubramaniam, M.V. 1989. Studies on the ecology of butterfly pollination in South India. Annals of Entomolology, 7: 31-41.

Daehler, C.C. 2003. Performance comparisons of co-occurring native and alien invasive plants: implications for conservation and restoration. Annual Review of Ecology, Evolution and Systematics, 34: 183-211.

Dafni, A., Kevan, P.G., Husband, B.C. 2005. Practical Pollination Biology, 590 pp., Enviroquest Ltd., Cambridge, Canada.

Dupont, Y.L., Hansen, D.M., Valido, A., Olesen, J.M. 2004. 2002. Impact of introduced honey bees on the native pollination of the endemic. Echium wildprettii (Boraginaceae) on Tenerife Canary Islands. Biological Conservation, 118: 301-311.

Faegri, K., van der Pijl, L. 1979. The Principles of Pollination Ecology, 244 pp., Pergamon Press, Oxford, New York.

Kushwaha, S.P.S., Ramakrishnan, P.S., Tripathii, R.S. 1981. Population dynamics of Eupatorium odoratum in successional environments following slash and burn agriculture. Journal of Applied Ecology, 18: 529-535.

Larson, D.L. 2008. Invasive plants and pollinator interactions. Endangered Species Bulletin Fall 
2008, 33: pp. 46-49, USGS Northern Prairie Wildlife Research Center, Minnesota, USA. Moragues, E., Traveset, A. 2005. Effects of Carpobrotus spp. on the pollination success of native plant species of the Balearic Islands. Biological Conservation, 122: 611-619.

Richardson, D.M., Allsopp, N., D’Antonio, C.M. Milton, S.J., Rejmanek, M. 2000. Plant invasions the role of mutualisms. Biological Reviews, 75:
63-93.

Traveset, A., Richardson, D.M. 2006. Biological invasions as diruptors of plant reproductive mutualisms. Trends in Ecology and Evolution, 21: 208-216.

Van Doorn, W.G. 2002. Does ethylene treatment mimic the effects of pollination on floral lifespan and attractiveness? Annals of Botany, 89: 375383. 